USAD, Bahar 2021; (14): 35-60

E-ISSN: 2548-0154

\title{
THE LEAVED CROSS AND CRESCENT BENEATH THE CROSS ON BYZANTINE ANONYMOUS FOLLES: AN INTERPRETATION OF GROUPS H, I, AND J, $\mathbf{M}^{* *}$
}

\section{BİZANS ANONIM FOLLISLERINDE BITTKISEL BEZEMELİ HAÇ VE AY ÜZERINDE HAÇ TASVIRİ: $H, I, J, M$ GRUBUNUN DEĞERLENDÍRILMESI}

Nergis ATAÇ**

\begin{abstract}
Before the years of approximately 1071-1092, the leaved cross and crescent beneath the cross appeared on Byzantine coins only in miniature size and typically as part of a scene focusing on the emperor. The motifs were generally widespread in the artwork of the provinces rather than the capital, Constantinople. Signifying death and resurrection, their appearance in the eleventh century in imperial Byzantine artwork points to influences of diverse cultures flocking to Anatolia and reflects the political and economic climate in the region. Did the increasing prominence of the leaved cross and the crescent beneath the cross in the eleventh century signal some type of agreements between the Byzantines and other new states to mint and circulate anonymous folles? While I support past

* Dr., Ankaral Türkiye, nancytuba@yahoo.com, https://orcid.org/0000-0002-8598-6029

${ }^{*}$ I am grateful to the Erzurum Archaeology Museum and the Benaki Museum, Athens for providing photographs.
\end{abstract}


theories that these folles were minted in Constantinople, some coins may have been minted in provinces and signified agreements between the empire and the new conquerors. This paper highlights the development of the leaved cross and crescent beneath the cross in Byzantine imperial art and draws attention to the non-Byzantines (e. g. Armenians, Georgians, Turks) in Anatolia in relation to the Byzantine anonymous folles (Group H, I and J, M) in eleventh-century Anatolia. Furthermore, I question whether the Byzantines might have implemented an integration policy as the Byzantine historian Michael Attaleiates put forward.

\section{Keywords}

Byzantine, Anonymous Folles, Leaved Cross, Crescent, Coins, Medieval Anatolia.

$\ddot{O} z$

Bizans sanatında bitki ve ay üzerinde haç motifi sikkelerde yaklaşık 1071-1092 yıllarından önce yalnızca minyatür denilecek boyutta ve tipik bir şekilde imparatora odaklanan bir sahnenin parçası olarak betimlenmiştir. Motif on birinci yüzyıldan önce başkentten ziyade "Bizans eyalet" sanatında yaygin görülmektedir. Ölüm ve yeniden dirilişle ilişkilendirilen motiflerin, on birinci yüzyılda sarayla bağlantılı sanatta yer almaya başlaması, Anadolu'ya akın etmiş çeşitli kültürlerin etkisini ve dönem ortamının yansımasını düşündürür. On birinci yüzyılda artış gösteren bitki ve ay bezemeli haç tasviri Bizanslılar ve yeni kurulan devletler arasında sikke basılması ve sirkülasyonu konusunda çeşitli anlaşmalara mi işarettir? Bu bağlamda anonim follislerin darp yeri konusunda Konstantinopolis monopolü görüşünü kabul etmekle birlikte, Konstantinopolis'in yan sıra yerel darphanelerin de olabileceği ve imparatorlukla yeni fatihler arasında anlaşmalar ifade etmiş olabileceğ $i$ savunulmuştur. Çalışmada, bitki ve ay üzerinde haç bezemelerinin İstanbul saray sanatında gelişimin anonim follislerle (Grup H, I ve J, M) bağına ve bu follislerin Gürcü, Ermeni ve Anadolu Türkleriyle ilişkisine dikkat çekilmiştir. Son olarak, çalışmada Bizanslıların, Attaleiates'in öne sürdüğü gibi bir entegrasyon politikası yürütmüş̧ olabileceği tartışılmıştır.

\section{Anahtar Kelimeler}

Bizans, Anonim Follis, Bitkisel Bezemeli Haç, Ay, Sikke, Orta Çă̆ Anadolu 
Although previously manifested in Christian art, the leaved cross and the crescent beneath the cross appear for the first time as a full reverse motif on the Byzantine anonymous folles (Photo 1-3) in the eleventh century. ${ }^{1}$ Numismatists classify these coins in Groups H, I, and J, M and date them between 1071 and 1092 (Grierson, 1993, 3, pp. 634-706, Pl. LXVIII).
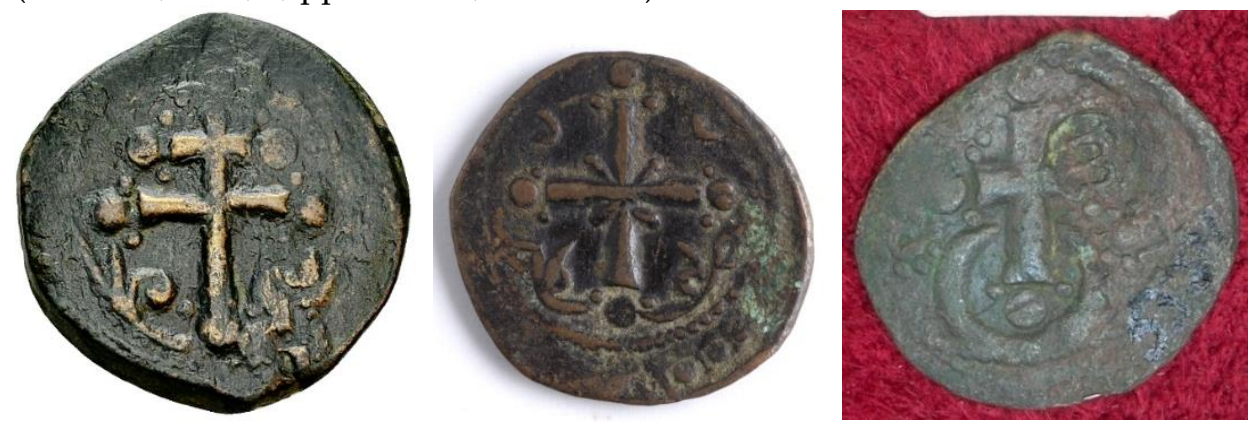

Photo 1. Leaved cross, Group H Byzantine anonymous follis

(https://www.coinarchives.com/0d8933c40d62790049fde7c223b481ea/img/auctiones gmbh/030/image00100.jpg) (accessed 03 June, 2019)

Photo 2. Leaved cross, Group I Byzantine anonymous follis (Photo: Courtesy of Benaki Museum)

Photo 3. Crescent beneath the cross, Group J Byzantine anonymous follis (Photo: Courtesy of Erzurum Archaeology Museum)

Yet numismatists, without a comprehensive explanation for the choice of the motif on the coins, propose a common signification of resurrection and victory of

\footnotetext{
${ }^{* *}$ I am grateful to the Erzurum Archaeology Museum and the Benaki Museum, Athens for providing photographs.

${ }^{1}$ Recently, Ünal and Demirel Gökalp have conducted considerable research on Byzantine coins in Turkish museums, which provide substantial data on Byzantine anonymous folles (Demirel, 2009; 2014; Ünal, 2012). For Byzantine anonymous folles in Bolu, see K1liç, 2016, pp. 315-339; for Kayseri, see Métivier, \& Prigent, 2010, pp. 577-618; for Balıkesir see Ünal, 2010, pp. 85-108; for Ani, see K. Mousheghian, A. Mousheghian, Bresc, Depeyrot, \& Gurnet, 2000. High numbers of anonymous coins find in Athens may be related to the return of the crusades and trade activities. For the Athenian Agora excavation see Thompson, 1954.
} 
the cross in the perpetual wars against Islam. ${ }^{2}$ These explanations neglect developments in Constantinople and also contradict the empire's eroding power in the eleventh century. For instance, even during the reign of Basileus II Bulgaroktonos (963-1025), emperors and administrators were more concerned with keeping their crowns than preventing death and destruction in Anatolia ${ }^{3}$. In the interest of keeping power, they did not hesitate to attempt to weaken their potential rivals among the Eastern troops of the empire and seek the help of Turkic armies against their own people. The situation progressed to a point where the emperor's power depended on the help of the Turkic armies sent by Turk sovereigns, the new rulers of most of Anatolia. ${ }^{4}$ On the other hand, the production of the anonymous folles started with the Muslim conquest of Anatolia and ended again with their temporary retreat from the region (977-1092) (Metcalf, 2006, p. 286). Consequently, the anonymous folles must be related to Anatolia.

The leaved cross, although in miniature size, was first featured on the histamenon of Group I during the reign of Constantine Monomachos IX (1042-1055). The motif decorated the top of a scepter held by the emperor in his right hand, and the crescent, on the bottom of a globe in his left hand (Grierson, 1993, 3, Pl. LVIII, 1b). The pattern, although not limited to a specific region, was mostly used in

${ }^{2}$ For arguments, see Grierson, 1993, 3, pp. 176, 637; for the first classification and first arguments, see Bellinger, 1928, pp. 1-27; for a recent and comprehensive study on Byzantine coins, see Morrison \& Schaaf, 2015. For Thessolonike see Morrisson, 2003, pp. 173-203.

${ }^{3}$ According to Psellos, Basileus II imposed hard taxes and confiscated the goods and estates of the powerful families posing a threat to the emperor (Charanis, 1975, pp. 16-17; Psellos, 1926, Vol.1, XXVIII, pp. 16-17).

${ }^{4}$ The Turks were rewarded by the emperors with land, precious metals, and gifts and were preferred to the rebellious Christians and the West (Attaleiates, 2012, pp. 332-587; Bryennios, 2008, p. 93). For example, Emperor Michael VII made an agreement with the Turks for capturing and delivering the rebellious Roussel de Bailleul. Bailleul at that time was protecting the people of Amaseia (Amasya) against the Turks and other invaders. He acted independently of the emperor and received his payment directly from the people of Amaseia. When he was caught by the Turks, the emperor ordered the people of Amaseia, who were then deprived of protection, to pay the Turks the sum of payment he had promised (Anna Comnena, 2000, I.II-III, pp. 7-9).

Nicephoros III gained the throne with the help of Chrysoscule, referred to as Emir Guedridj-Erisgen bin Yunus Yabgu bin Seljuq, cousin of Suleiman Shah and husband of the sister of Alp Arslan (Attaleiates, 2012, pp. 481-487; Melikoff, 1960,1, p. 80, n. 3). Chrysoscule later served the empire and became proedros. The emperor thus allowed the army of Suleiman Shah to settle in the Nicaea (İznik) garrison. Suleiman Shah also helped Nicephoros Melissenos to gain the throne against Nicephoros III, in return for half of the cities to be taken away from the emperor. In 1086, Abu 'l Qasim became sebastos and received regular payments from the empire (Beihammer, 2017, pp. 267-268). Numerous similar facts could be found in Byzantines sources. 
provincial art (e.g. Thessalonike funerary rooms). ${ }^{5}$ Although it was used in one of the panels in the church of St. Sergios and Bachos in Constantinople, the origin and faith of the priests of this church are debatable (Croke, 2006, pp. 25-63). During Iconoclasm, the leaved cross is prominent, but there is no evidence that the motifs increased in number. On the other hand, its use in the church of Ürgüp Karacaören in Cappadocia and the inscription in the church of St. Basileus in Sinasos stating that Christ cannot be illustrated by an image draw attention to Iconoclasm (Photo 4). The motif, however, is found in many churches in Cappadocia, especially from the beginning of the ninth century (e.g. Mavrucan No.3, Hagios Stephanos in Cemil, Anna and Joachim in Kızıl Çukur, Üzümlü), which demonstrates a decoration particularity of the region. Moreover, the designs illustrate manuscripts such as Paris MS. gr. 510'da (867-886). The full folio proves that it could not be traced to Iconoclasm, and in fact, it was used by the Iconophiles to illustrate the two natures of Christ. ${ }^{6}$

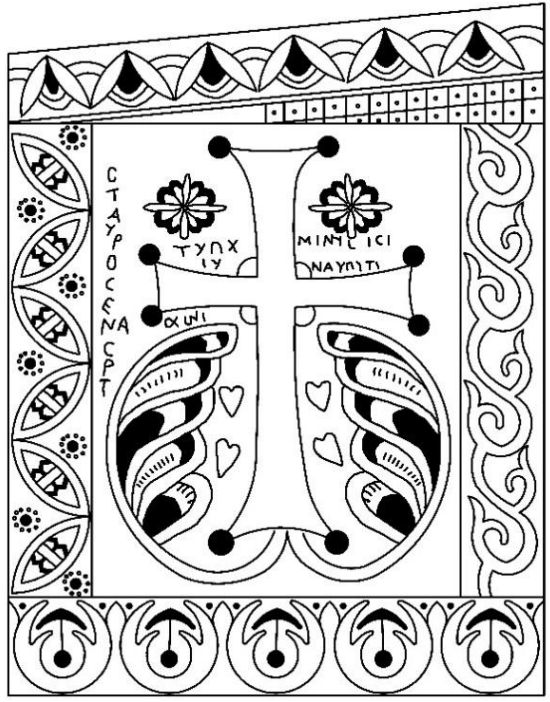

Photo 4. Leaved cross, the church of St Basileus in Sinasos, Cappadocia (Drawing: Nergis Ataç after Thierry, 1971, p. 137, fig. 72)

\footnotetext{
${ }^{5}$ The leaved cross, signifying the resurrection, can be found in Byzantine churches, chapels, illustrated manuscripts, minor art, architectural elements and sculptures. For various examples, see Rice, 1973, Vol. 7, pp. 72-81.

${ }^{6}$ After the Iconoclasm, the leaved cross is illustrated as a full folio in the Paris Ms. 510 gr. manuscript of Emperor Basileus I. Brubaker asserts that the manuscript was ordered by Patriarch Photios as a gift to the emperor as a propaganda agent (Brubaker, 2008, pp. 412-416). According to Robert H. Hewsen (2001, p. 92), patriarch Photios is of Armenian origin.
} 


\section{Constantinople and the Provinces}

Apart from the staurothekes produced in Constantinople, the leaved cross has limited examples in the capital. ${ }^{7}$ The prominent illustrations in religious and imperial art were of Christ, the Virgin and saints. ${ }^{8}$ The low representation in Constantinople was countered with the increase in the seals of the tenth century, especially in Anatolia, Chaldia, Armeniakon, and Thessalonike (Nesbitt, Oikonomides \& McGeer, 1994-2005, Vol. 2-5). ${ }^{9}$ The leaved cross motif began to spread in Constantinople and in the imperial art only after the eleventh and twelfth centuries. ${ }^{10}$ In the twelfth century manuscripts, especially in the Homilies of the Virgin Mary written by St. John Jacobos, Vat. Gr. 1162, the roofs of churches are decorated with a leaved cross, a type on the church roof not identified before the twelfth century. The few examples on church roofs found before this century are simple crosses with no leaves. Thus, the leaved cross seems to exceed its original meaning, mainly restricted to burial and resurrection in chapels and on staurothekes, and came to represent the church in the second half of the eleventh century. The presence of the design in the church of the Monastery of St. Daphne built by Constantine IX Monomachos (1042-1055) and decorated by the Comnenos dynasty (1081-1185) proves that it had become widespread not only in the art of Constantinople but also in the art produced or constructed with the support of the court in provinces. Its frequent use beginning at the end of eleventh century in the art of the capital, or in regions influenced by the capital, must be related to anonymous folles. Its appearance on the reverse of the folles (H-I) as a single motif, is strikingly new and raises the following question: How did the leaved cross

7Theopanos Continuatus reported that Basileus I the Macedonian (867-886) had Armenian ethnicity (Arsacid) (Theophanes Continuatus, 1838, V, pp. 212-216. For arguments see Tobias, 1969, p. 34. For staurotheke examples, see Evans, \& Wixom, 1997, pp. 78-79, No. 37, No. 38, and the Limburgan-der-Lang staurotheke.

${ }^{8}$ For holy figures on Byzantine coins, see Ünal, 2015.

9 Dumbarton Oaks online catalogue: https://www.doaks.org/resources/seals. See also Cheynet, Gökyıldırım \& Bulgurlu, 2012; Nesbitt et al., 1994-2005, Vol. 2-5; Schlumberger, 1884.

The empire and the Eastern Christian people were united against the Abbasid caliphate in the tenth century. Emperor Tzmisces must have intentionally used IhSYS XRISTYS bASILEY' BASILE (King of kings Jesus Christ) on his coins (Grierson, 1993, 3, p. 634). The emperor, in need of the help of eastern Christians not under his sovereignty, brought together the Armenian, Georgian, and the Eastern Christian people, under one umbrella, that of Jesus Christ instead of the Byzantine emperor. Basileu Basile refers to both rex regnantium and şahinşah. Tigran II, son of Armenian King Artzavades, used $B A C I \Lambda E[\Omega \Sigma] B A C I \Lambda E \Omega[N]$ (King of kings) on his coins (Tekin, 2014, pp. 40-42). It is strange that after the death of Tzimisces I, the older Smbat II used şahinşah, and his brother, Gagik I, continued to use the same titular (Jones, 2001-2002, p. 368).

10 See for example Bibliothèque nationale de France, gr. 1208, fol. 3v and Bibliotca Apostolica Vaticana, Vat. Gr. 1162, 2v. 
expand outside Byzantine provincial art and progress to become one of the symbols of the court and in imperial art? Alexander Saminsky's (2006, pp. 17-78; 2013, pp. 219-276) research on Antiochian manuscripts in Anticoh on the-Orontes in Syria and Armenian monasteries round Antioch sheds light on understanding the progression.

These manuscripts make two crucial points for our argument: The prominent use of the leaved cross in these manuscripts cannot be ignored, and the date of the manuscripts is very close to the date of the Group H-J folles. According to Alexander Saminsky's (2006, p. 18; 2013, pp. 219-276) research, some manuscripts previously identified as originating from Constantinople were, in fact, of Antiochian origin. Furthermore, the author asserts that the Athos manuscript from Koutloumousio Monastery MS. 61 must be analyzed in this context. He concludes that the Georgian Alaverdi Gospel Tbilisi, Institute of Manuscripts, A 484 (1054), may be the model of origin. According to the author, although this manuscript shows similarities to the Athens 57 manuscript influenced by the capital style, differences emerge in aesthetics. ${ }^{11}$ Therefore, a close relation between Constantinople and the region of Antioch in the mid-eleventh century cannot be ignored. What must also be underlined is the fact that important ArmenianGeorgian scriptoria centers were active in the region of Anatolia and Antioch and that they had a close relation with Constantinople. However, these schools, although open to Constantinople influences, retained their Syrian or ArmenianGeorgian characteristics.12 The second fact to be highlighted is that in the manuscripts produced in this region (e.g. Tbilisi, Institute of Manuscripts A 484), the leaved cross is prominently illustrated in the manuscripts produced in the eastern regions at a time when it was not as popular in Constantinople.

What is the relation of regional stylistic or iconographic differences in the business of money minting? When the iconographic interpretation of coin finds is

${ }^{11}$ The Alaverdi Gospel (Tbilisi, Institute of Manuscripts, A 484) is composed of a collection of the Abgar myth manuscript and the four gospels. It was produced in the Georgian Monastery of the Virgin (nearby the Monastery of the young Simon) at Kalipos Monastery in Antioch (the Black Mountain) in 1054. For other Antiochian-influenced manuscripts, see Saminsky, 2006, pp. 17-78; 2013, pp. 219 276.

${ }^{12}$ Nikon of Mount Amanos reported the existence of Armenian monks of Chalcedon dogma around Antioch (Saminsky, 2013, p. 224). Because of the pressure of Muslim ostikans, the Byzantine invasions, and later, that of Turks in the middle of the eleventh century, many Armenians and Georgians fled to the ducate of Antioch. Some found refuge in the Mount Amanos monasteries and produced manuscripts besides performing their daily liturgy and celebrations (Honigmann, 1970, pp. 215-224; Weitenberg, 2006, pp. 79-.93). Some, after crossing these regions, went to Macedonia (Garsoïan, 1998, pp. 53-124; Honigmann, 1970). 
analyzed together with historical facts, the argument of a provincial mint, discussed comprehensively first by Metcalf, eventually emerges. ${ }^{13}$ Some historical developments, such as long-term invasions, are certain to affect coin circulation. But scholars agree that high circulation of one type of coin does not prove provincial mint. However, although iconographic differences are overlooked, security and various interest conflicts of the second half of the eleventh century cannot be ignored. Most regions of Anatolia and the Balkans were re-isolated from Constantinople because of invasions and conquests (Altan, 2018). Furthermore, the inner regions were out of Byzantine control, and the shores were governed in "autonomy".

Four autonomous regions are especially important to our subject: Antioch, Nicaea, Thessalonike, and Trebizond. The style and quality of folles produced in the Trebizond region under Theodoros Gabras show similarities to Anatolian examples. But in this article, Gabras's folles won't be examined in detail. ${ }^{14}$

The coin mint at Antioch was important because it was one of the few mint centers in the Byzantine Empire until the arrival of the Muslims. ${ }^{15}$ It's unclear whether the mint resumed coin production after the Byzantines re-conquered the city. However, a relation between Antioch and Constantinople can be determined from the coin finds of Antioch (Metcalf, 2006, pp. 283-318). ${ }^{16}$

According to Cheynet (2006, pp. 13-16), the autonomy issue was not the cause but the result of security problems. With the arrival of the Turks, inter-road problems arose for the Byzantines. Important trade-religious-cultural centers like Antioch, and cities rich in metal, like Melitene and Kharpet (Harput), were isolated from the capital (Altan, 2018, p. 17; Cheynet, 1996a, pp. 402-404). Although this did not lead to a full disintegration of the empire, the increasingly autonomous power of the rulers of these cities was a disadvantage for the capital. For example,

${ }^{13}$ According to some numismatists, the 'secret marks' on anonymous folles may be related to mint, to others related to chronology. Grierson, further asserts to "dispose completely of the idea" of a single provincial mint for all the pre-Alexian signed coins (Grierson, 1993, 3, pp. 640-643; Metcalf, 1961, pp. 25-32; 1965; 1970, pp. 199-219).

${ }^{14}$ According to Schulze (2008, pp. 321-330), some types attributed to Gabras are produced in Antioch. For the alleged Trebizond folles during the Gabras period, see Bendall, 1977, pp. 126-136; Schulze, 2008, pp. 321-330; Schulze \& Moesgard, 2005, pp. 339-347.

${ }^{15}$ The mint was shut down when the Muslims conquered the region in the seventh century (Grierson, 1993, 2, 1, p. 219). Nicephoros II and Tzimisces I, both of eastern origin, must have been aware of the richness of natural resources and trade routes in the East, and hence, turned their imperial policy toward the eastern regions.

${ }^{16}$ On the other hand, the high number of signed folles of Nicephoros III and Alexius I in the city prove a continuing influence of the empire in the region. The high number of 'secret marks' folles of the A2 group against the A1 group (164:1), suggests that maybe some varieties of these folles were produced in a provincial mint. 
Nicephoros III Botaneiates (1078-1081) wore the crown in the presence of the patriarch of Antioch in Nicaea, while Michael VII Doukas (1071-1078) was still on the throne (Attaleiates, 2012, p. 491). The security of roads and troops were provided by the Turks. The newly "crowned" Nicephoros III, even though he had the support of the Turks and Antioch, may have still felt insecure and married Empress Maria of Alania, wife of the former emperor, while the former emperor was still alive (Anna Comnena, 2000, I.XII, p. 23). ${ }^{17}$ Thus, the empress's brother, Giorgi II (1072-1089), was awarded the title, caesar, by the new emperor, Nicephoros III. King Bagrat IV of Georgia (1027-1072), Maria's father and the father-in-law of Nicephoros III, married his sister's daughter to the Sejuk Sultan Alp Arslan (Beihammer, 2017, p. 136). Nicephoros III's vision was not limited to Constantinople. He managed to secure the help of the Turks, the Georgian Kingdom and the Chalcedonian Armenians, the ducate of Antioch. ${ }^{18}$

Apart from the ducate of Antioch and Anatolia, two other regions were important for circulation: Thessalonike and Mount Athos. The coin mint in Thessalonike nearby Constantinople was closed in about AD 630 and most likely resumed between the ninth and eleventh centuries (Cecile, 2003, pp. 173, 174-203). But the security restored by Basileus II deteriorated from the invasions of the Balkans by the Normans, Petchenegs, and Cumans. With the military help of Suleiman Shah, Alexius I Comnenos (1081-10118) regained control of the western regions but lost the Anatolian territories in the years of 1081-1085 (Beihammer, 2017, pp. 226-231; Cheynet, 1996a, p. 404). On the other hand, we still recognize a relation between Constantinople and the West from privileges granted to eastern magistra sent to the West. Alexius I sent Magistros Pakourianos to control the western regions, and in return, with the chrysobullos, the emperor gave him some estates and land with full revenue (Lemerle, 1977, pp. 135-136). Pakourianos was of Iberian origin, owned considerable land in the region and relied on the Ducate of Antioch. It is notable that although Pakouriaous was the right hand of the emperor, and faithful to the Chalcedonian dogma, he ordered an interdict of entrance into his monastery to the Greeks, but opened his door to Armenians and

\footnotetext{
${ }^{17}$ Maria of Alania was the wife of emperor Michael VII and emperor Nicephoros III, and daughter of the King Bagrat IV of Georgia. Although the marriage violated the orthodox canon, the new emperor must have had a good reason to force the issue. Byzantine sources attribute his intention to the beauty of the empress, but Maria's connection to the Georgian Kingdom most likely played an important role.

${ }_{18}$ According to Attaleiates (2012, p. 405), Nicephoros III is of Iberian origin. The author related the western Iberia to the eastern Iberia.
} 
called them "brothers," while at the same time, saying that they were heretics. ${ }^{19}$ Emperor Alexius I granted similar privileges of land and revenue in Thessalonike to the former monostrategos of Anatolia, Nicephoros Melissenos (Cheynet, 1996a, pp. 403-404). ${ }^{20}$

The close relation between the eastern and western provinces is also evident in the art of Macedonia and Anatolia. Concerning this intersection, Mount Athos although not related to money minting- must be mentioned: Mount Athos, supported by various donors, was a central base for religion and art, though it had little to no military importance. The Mt. Athos Iviron and Krakallou monasteries, and numerous visiting Georgian priests demonstrate that the region drew influence from geographic areas far beyond Constantinople. Saminsky's research, previously mentioned, reveals this relation. The connection between these regions was already salient in the period of Nicephoros II Phocas (963-969) and John I Tzimisces (969-976), supporting monasteries in Mount Athos and Anatolia.

\section{Maria of Alania (Mart'a, Martha)}

Maria of Alania, daughter of the king of Georgia Bagrat IV, was an important donor in the region (e.g. Mt. Athos Iviron Monastery) (Kalavrezou, 2011, pp. 85101). The empress also had some estates in the West. ${ }^{21}$ A connection between Maria's ring found in Petritzos and the monastery of Petritzos founded by the Iberian magistros Pakourianos has yet to be thoroughly analyzed. It is perhaps not in vain for Attaleiates (2012, p. 405) to relate the western Iberia to the eastern Iberia.

The date of the appearance of the leaved cross on anonymous folles, Groups $\mathrm{H}$ and I, during the crowning of Maria as empress is a phenomenon that also has yet to be addressed. Maria was married to Emperor Michael VII and Emperor Nicephoros III (Anna Comnena, 2000, I.XII, p. 23). In one of the enamel plaques of the Xaxuli (Khahkouli) triptych illustrating the crowning of Michael VII and Maria of Alania, Maria holds a scepter decorated with a leaved cross. On the other hand, the first known illustration of the leaved cross scepter is on the seal of Maria

\footnotetext{
${ }^{19}$ My highlighting of ethnicity and region is to underline them as an issue of the period. According to the typicon of the monastery, Pakourianos witnessed the pillage of Iberian monasteries by the Greeks and wanted to avoid the same damage to his monasteries (Lemerle, 1977, pp. 149-150, 185186).

${ }^{20}$ Nicephoros Melissenos, with the help of Turks, revolted against Emperor Nicephoros III. But he made an agreement with Alexius I and ended his revolt in 1081 in return for the caesar title and land revenue. For the title and seals of Nicephoros Melissenos, see Dumbarton Oaks' online catalogue.

${ }^{21}$ Maria's estates were located in Christoupolis (Kavala), Pernikos (Pernik) and the Petrizos castronon the northern slopes of Rhodope Mountain. A ring with an inscription of 'Maria Botaniatina' was found during an excavation in the complex of a monastery (forbidden to women) located at Mount Papikion in West Trachaeia. The ring suggests that she may be the patron and was entombed in this monastery (Georganteli \& Cook, 2006, p. 48; Papathanassiou, 2010-2015, pp. 59-97).
} 
Skleraina (d. 1045) (Photo 5). The seal was previously known to belong to Maria of Alania. However, with the correction of Cheynet (2008, p. 195), because of the inscription of Sebasta, the figure of the woman holding the leaved cross scepter appeared to be Sebasta Maria Skleraina. Obviously, the leaved cross and the crescent illustrated on the histamenas of Monomachos IX (1042-4055) and the seal of Sebasta Maria Skleraina are related.22 The same type of scepter is illustrated later on the seal of the empress Theodora (1055-1056) (Photo 6) (Campagnolo-Pothitou \& Cheynet, 2016, p. 26). A lead seal decorated with a leaved cross was not unknown in the empire. However, a scepter and globus with a leaved cross began to be illustrated in the court art during the reign of Constantine IX Monomachos. Contantine IX had Alanian (niece of Bagrat, king of Georgia) and Armenian (Maria Skleraina) mistress'. The Alanian mistress was a close relative of Maria of Alania (Garland, \& Rapp, 2006). According to the Life of Giorgi Mt'acmideli (1009-1065) (abbot of Mt. Athos Iviron Monastery) Maria was also well connected to Theodora:

For at the time, when the kingdom of the Greeks was ruled by Queen T'eodora [Theodora], she asked the king of the Ap'xaz Bagrat to give his daughter Mart'a so that she might be brought up as her own child. ...when Queen Theodora passed away, they led Mart'a, the daughter of Bagrat, into the kingdom... And when the holy man [Giorgi] saw Mart'a, within everyone's ear-range he prophesied, saying that: 'Let everyone know that today the Queen has departed and the Queen has arrived. (Garland, \& Rapp, 2006, para. 5)

When Maria of Alania became empress, she brought with her Alan advisors. Furthermore, the Tornikioi, the Pakourianoi, Skleroi, Phokades, and the Dalassenoi were descendants of powerful Iberian (Armenian-Georgian) familes in the eleventh century. In the Homilies of John Chrysostom cat. No. 143, fol. I (2bis) v., in which Maria is crowned first with her first husband, Emperor Michael VII, and then his figure erased for the figure of the new husband, Nicephoros III (an Alan), Maria

${ }^{22}$ The crescent is also illustrated in the miliaresion of Emperor Nicephoros III and Empress Maria (Grierson, 1993, 3, Pl. LXIX, B6). This type is almost identical to the miliaresion of Basileus II. Emperor Basileus II by re-conquering the eastern Iberian regions and in the west, the Balkans, restored security in the empire. Although he is popular as the Boulgaroktonos, he is praised and well esteemed in Armenian-Georgian sources. For Basileus II miliaresion, see Grierson, 1993, 3, Pl. XLVI, pp. 18-20.

Maria Skleraina, life partner of IX Monomakhos, was titled sebasta, and was third in the hierarchy of the court right after Zoe and Theodora (Seibt, 1976, p. 72). For her seal see Cheynet, 2008, p. 195; Nesbitt Wassiliou, \& Seibt, 2009, pp. 34-36.

The scepter with a leaved cross decoration is also found in the marble carving of the emperor figure dated to the twelfth century. Although it is dated after Maria's examples, a re-evaluation may be necessary. For the marble carving sample, see Maguire, 1997, p. 200, No. 137. 
holds a scepter with a leaved cross (Photo 7). Thus, the type of the leaved cross scepter of Maria decorates the crown of King Geza (1074-1077). The crown was a gift sent to the king by Michael VII and Maria.
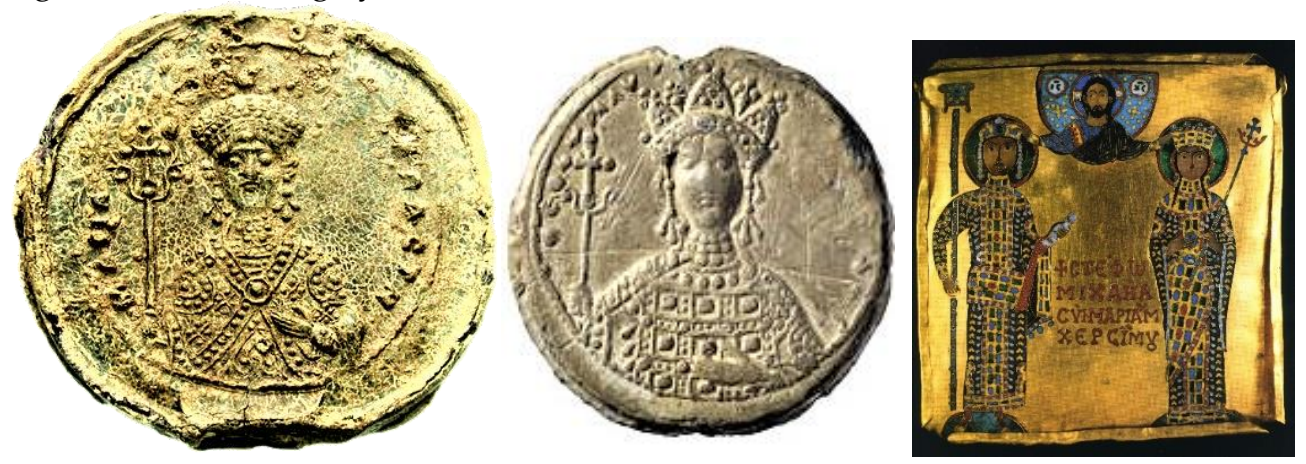

Photo 5. Scepter decorated with a leave d cross, lead seal of Sebasta Maria Skleraina (d. 1045) (Cheynet, 2008, p. 195)

Photo 6. Scepter decorated with a leaved cross, lead seal of Empress Theodora (10551056) (@ 2020 - Musée d'art et d'histoire de Genève, 48)

Photo 7. Scepter decorated with a leaved cross, the crowning of Michael VII and Maria of Alania, Xaxuli (Khahkuli) triptych panel (G. Koch, 1984)

Either way, the cultural milieu of the female 'ruler' holding the leaved cross scepter was not much different: Maria Skleraina (d. 1045) was a member of the Skleroi family in Armenia Minor and Theodora probably herself a descendant of Arsacid, had an Iberian inner circle. ${ }^{23}$ Maria of Alania became empress in 1071, just two decades after the death of Maria Skleraina. Similar motifs use by both women, who are noble Georgian-Armenian descendants and rose up with similar cultural influences, is not surprising. The spread of these motifs in regions populated by Armenians and Georgians, either due to forced or voluntary migration, are evident in illustrated manuscripts, sculpture decoration and kachkars dated to the eleventh century. Although Maria of Alania was an empress in the last quarter of the eleventh century, she must have been familiar with the art from earlier in the century. She was not only a benefactress to a considerable number of monasteries but also the patroness of minor art (Kalavrezou, 2011, pp. 85-101; Papathanassiou, 2010-2015., pp. 59-97). However, we must admit that although Empress Zoe pressed her favorite icon of Christ Antiphonetes on coins, Maria's position as an empress and daughter of a king doesn't prove her power to influence state symbols

\footnotetext{
${ }^{23}$ For Maria see Seibt, 1976, pp. 71-76. For the genesis of the Macedonian dynasty see Theophanes Continuatus, $1838, \mathrm{~V}$, pp. 212-216.
} 
or choice of motifs on state coins. Moreover, the widespread use of the motif in the ducate of Antioch and regions populated by Iberians in the eleventh century does not justify a provincial mint. On the other hand, the appearance of the leaved cross on the Groups $\mathrm{H}$ and I folles and in the imperial art connected to Maria, and right after the Groups H-I, the appearance of the crescent beneath the cross on Group J and $\mathrm{M}$ folles points to a close relation. De facto ruler/governor of Trebizond Theodoros Gabras, to whom an attribution of some of the mint of the group I, J, M folles is put forward, was married to a high-born lady of the Alani, most likely Maria's sister Mariam. ${ }^{24}$ Maria was no longer an empress during the reign of Alexius I, but nevertheless she was princess and mother of co-emperor Constantine (Anna Comnena, 2000, I.XII, p. 23). On a pre-reform coin of Alexius I, the emperor holds a leaved cross scepter similar to the scepter of Maria (Hendy, 1999, 4, 2, Pl. I, 3.5-3.6). Although the leaved cross and crescent motifs are detected in the art of the capital before the eleventh century, they were not common in imperial art, especially the imperial insignia. The identified examples are mostly staurothekes; few are lead seals and triptychs.

\section{Anatolia and the Turks}

When the Group H, I and J, M folles are analyzed, differences within groups arise in quality and style (Photo 8-13). The leaved cross folles found in the Kharpet (Harput) inner castle excavation present good examples for a query into the mint question (Photo 8). ${ }^{25}$ The Kharpet example has a leaved cross motif, but the style and quality present more of a copy. Also, its cross is closer to Group J and the cross models of Alexius I. Where and who may have produced these variants, aloof from the delicacy of Constantinople?
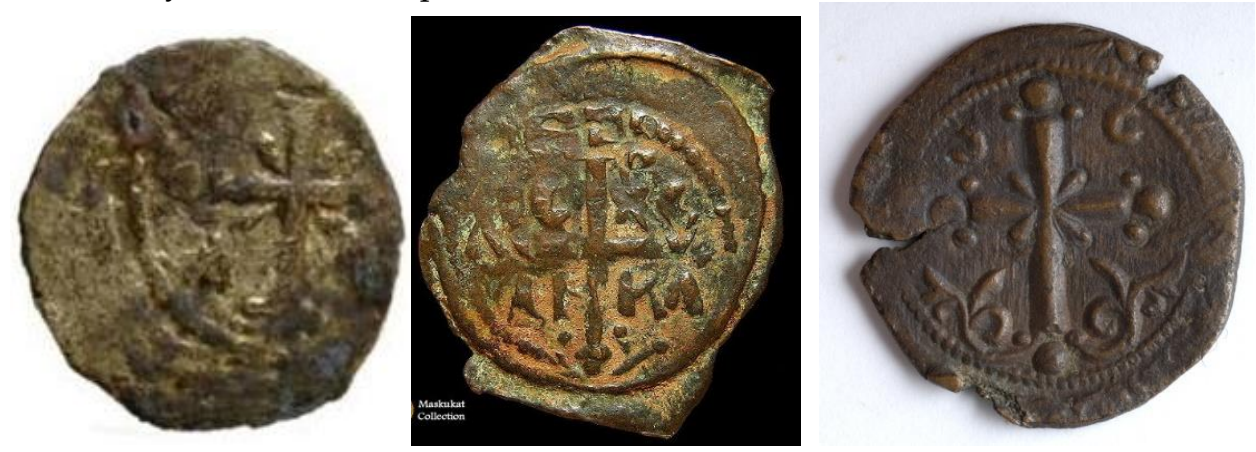

${ }^{24}$ For the coins see Bendall, 1977, 126-136, Pl. 6. For the high-born lady of Alania, a cousin of the wife of Isaac Comnenus, see Anna Comnena, 2000, VIII. IX, p. 150.

${ }^{25}$ The subject coins are finds from the excavation conducted by İsmail Aytaç (2017, pp. 140-153) in the years of 2014-2015. 
Photo 8. Kharpet inner castle excavation find, Group I anonymous follis (Aytaç, 2017, No: (2))

Photo 9. Crusader Principality of Antioch, leaved cross, copper follis of Tancred (11011103, 1104-1112)

(http://medievalcoins.ancients.info/crusaders/ANTTancredMetcalf66 $62 . J P G$ )

(accessed 05 September 2019)

Photo 10. Leaved cross, Group I anonymous follis (Photo: Courtesy of Benaki Museum)
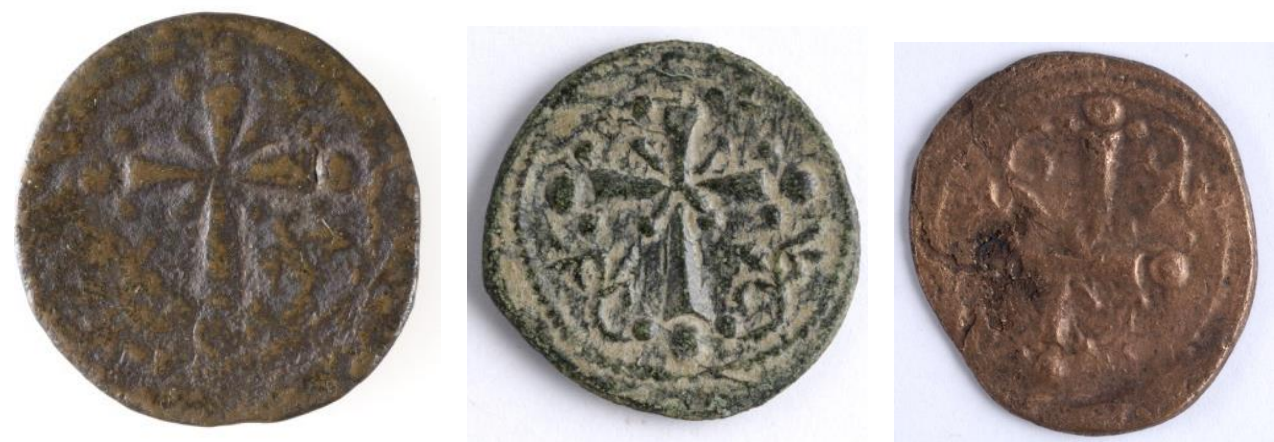

Photo 11. Leaved cross, Group I anonymous follis (Photo: Courtesy of Benaki Museum) Photo 12. Leaved cross, Group I anonymous follis (Photo: Courtesy of Benaki Museum) Photo 13. Leaved cross, Group I anonymous follis (Photo: Courtesy of Benaki Museum)

With the arrival of the Turks in Anatolia in 1071, Kharpet came under the autonomy of Philaretos Brachamios, but in 1085, the city was conquered by the Çubukoğulları (1085-1115) and after them by Balak, son of Bahram and descendant of Artuchis. ${ }^{26}$ The earliest dated coin of Turks found in this castle is of Malik Mehmed (1134-1142), son of Danishmendid amir Malik Gazi Gümüştegin (Aytaç, 2018, pp. 29-55).

The inscription on the coin is in Greek. No coin that has so far been studied by numismatists can be attributed to the Çubukoğulları, but neither Nicephoros III nor Alexius I had the reach of power to maintain centralized coin circulation in the region. Various agreements and mediators must have filled these voids. When Philaretos's autonomous regions were conquered by the Turks, Gabriel (Khoril) governed Melitene (Malatya) with the consent of the Great Seljuq Sultan Malik Shah, and Philaretos's old man Kourapalates Toros (Theodoros Hetum) governed

\footnotetext{
${ }^{26}$ Kharpet and Melitene were under the autonomous rule of Philaretos but later were conquered by the Turks in 1085. Kharpet was conquered by Çubuk Beg and Melitene by the uncle of Suleiman Shah. However, Melitene, in return for tribute and garrison, was autonomously governed by Philaretos's man, Gabriel (Cheynet, 2003, pp. 150-151; Oikonomides, 1986, pp. 103-105, No. 107). There are no certain details about the progression of the Kharpet governance.
} 
Edessa (Urfa) in the name of Buzan. The question of provincial Christian lords and administrations under the sovereignty of Turks has yet to be addressed (Beihammer, 2017, p. 255; Cheynet, 2006, p. 14). Cheynet (1996b, p, 80; 2003, pp. 137-151; 2006, p. 14) evincing the commemoration of Alexius I in an inscription found in Edessa, posits that the city, although under the sovereignty of Turks, was under the influence of Alexius I. Moreover, Gabriel and Toros, apart from the emir titular, continued to use the titular of kouropalatos bestowed by Alexius I. ${ }^{27}$ Therefore, these types of anonymous folles in regions under the sovereignty of Turks must be related to the already established provincial administrative power. Ani's sale to the Shaddadid (of Kurdish origin) and the lack of Group I-N folles in the city, with the exception of a few $\mathrm{H}$ specimens, indicate the possibility of involvement of the Turks in these folles. ${ }^{28}$

Furthermore, copies of Byzantine anonymous folles during the period of Bohemond I and Bohemond II in the Crusader Principality of Antioch, support the possibility of a provincial mint of Groups $\mathrm{H}$ and I in regions under the sovereignty of the Seljuqs until the twelfth century (Photo 9). ${ }^{29}$ The other important evidence is the hoard found during the salvage excavation of the Marmaray metro at Yenikap1 in Istanbul, which demonstrate a fairly high proportion of signed coins of Nicephoros III to anonymous folles group of H-J which is 148 to $8 .{ }^{30}$ The low number of group H-J in Constantinople is remarkable.

In addition, the Abbasid mints in the south of Anatolia, re-conquered from the Abbasids, further demonstrate the theory that these folles came from a provincial mint. The Abbasids, although lacking in copper, had gold and silver coins minted in these regions. Some of the caliphate's mints were in cities like Mardin (Marida), Diyarbakır (Amida), Masisa, Antakya (Antioch on the-Orontes) and Erzincan (Keltzene, Yerznka) (Diler, 2009). Although after the re-conquest of these cities by the empire, their coin production may not have been active under the Byzantine rule; some may have been active during the "autonomy" period.

\footnotetext{
${ }^{27}$ See also Oikonomides, 1986, pp. 103-104, No. 107.

${ }^{28}$ For a short chronology of Ani history and Ani coins, see Mousheghian, et al., 2000.

${ }^{29}$ In the Princeton excavation of Antioch, 28 Byzantine anonymous folles from Groups H-J are found with 74 specimens of Seljuq of Syria. Forty-three coins of the total Seljuq coins are decorated with animal figures, 31 with inscriptions (Metcalf, 2006, 290, 293). For the copper folles of Antioch see Metcalf, 2006, pp. 296-297, fig. 4.

${ }^{30} \mathrm{Oğuz}, 2009$, pp. 279-288. Of the total 176 coin finds, $142+6$ are signed folles of Nicephoros III, only five are from Group H, one from Group I and two from Group J. Group J confirms that the owner did not bury the hoard in the early years of Groups $\mathrm{H}$ and I. Therefore, we can suggest that the ratio of Groups H-J is low compared to the provinces. For the hoard of Marmaray metro at Yenikapı in Istanbul, see Tekin, 2009, pp. 279-288.
} 
Alexius I went as far as to smelt precious metal goods of churches to provide for the needs of troops and pay them during the war against the Normans in the West. This fact clearly demonstrates the desperate shortage of metal in Constantinople. In 1080, the Turks conquered all the territory from Cilicia to Marmara. The geographic isolation of the capital from the rest of the eastern regions must have affected the transfer of precious metal (Altan, 2018, p. 18). ${ }^{31}$ At the same time, Philaretos's tribute to the Turks must not be overlooked. Archaeological data and written sources reveal Byzantine coins in circulation in Anatolia. In that case, if Philaretos could not receive the required amount from the capital, which makes sense given that at the time the capital was not even able to provide for itself, where would he get the money to administer his autonomy?

In that context, the relation between regional art propaganda and political and military agreements may contribute to the discussion. What is the relation of motifs in Caucasian-Syrian art to the Byzantine anonymous folles? What is the possibility of a relation of these motifs on Byzantine anonymous folles to the arrival of the Turks in Anatolia or a forced or voluntary migration of Armenians and Georgians to Byzantine and Anatolian provinces? Although Byzantine and Seljuq sources report different views about the Turks in Anatolia, Attaleiates give an interesting point of ideology about Nicephoros III, bringing the Turks to the shore of the capital. According to Attaleiates (2012, pp. 392-393, 479, 481-491), the Turks of Anatolia are people escaping the sultan of Iran (sultan of the Great Seljuqs), seeking support and protection, and flocking to Nicephoros III, whom they believed to be the God-appointed rightful emperor. Although the emperor's priority must have been to wear the crown, Attaleiates's expression of non-Byzantines and Turks flocking and submitting to Nicephoros III may have been viewed as political key for the chaos in Anatolia. Perhaps when the empire lost power and might to fight militarily against the Barbarians, it may have sought their integration under the emperor and the cross. Common symbols on coins and insignia may have been one of the means for integration.

Grierson has rightly pointed out the relation of the motif of Group J folles to the Turks. According to Grierson (1993, 3, pp. 176, 637), the crescent was related not to the Muslims but to the Turks. I agree that the crescent was used by the Turks (Photo 17); however, the design was used in Islamic coins long before the rise of the Ottomans or Turks. ${ }^{32}$ The conserved Islamic coins reveal copies of Sassanian

\footnotetext{
${ }^{31}$ Alexius I, with the agreement of Dragos water in 1081, recognized Suleiman Shah's sovereignty in Anatolia.

${ }^{32}$ For the crescent symbol on the coins of Gokturk in the eighth century see Babayar, 2007, pp. 56-58; for Zangid/Eyyubid in the twelfth - thirteenth century see Uykur, 2017, pp. 167-183.
} 
coins. Therefore, the crescent, aside from the art of the Turks, was also widespread in the medieval art of the regions ruled until the sixth century by the Sassanian Empire (Photo: 14-16), which included present-day Georgia and Armenia. Armenian-Georgian artwork was influenced by Sassanian art.

On the other hand, I agree with Grierson that the crescent beneath the cross does not symbolize the victory of Christians over Muslims. In fact, during the date of Groups H-J between 1071 and 1092, Byzantines had no great victory, but defeat against the Muslims. Furthermore, even though the Turks were repelled from part of Anatolia, that victory belonged to the crusaders who were at the time as great an enemy of the Byzantines as they were of the Muslims. Besides, the Byzantines also achieved no military victory against the Iberians, who considered the crescent as a symbol of worship. ${ }^{33}$
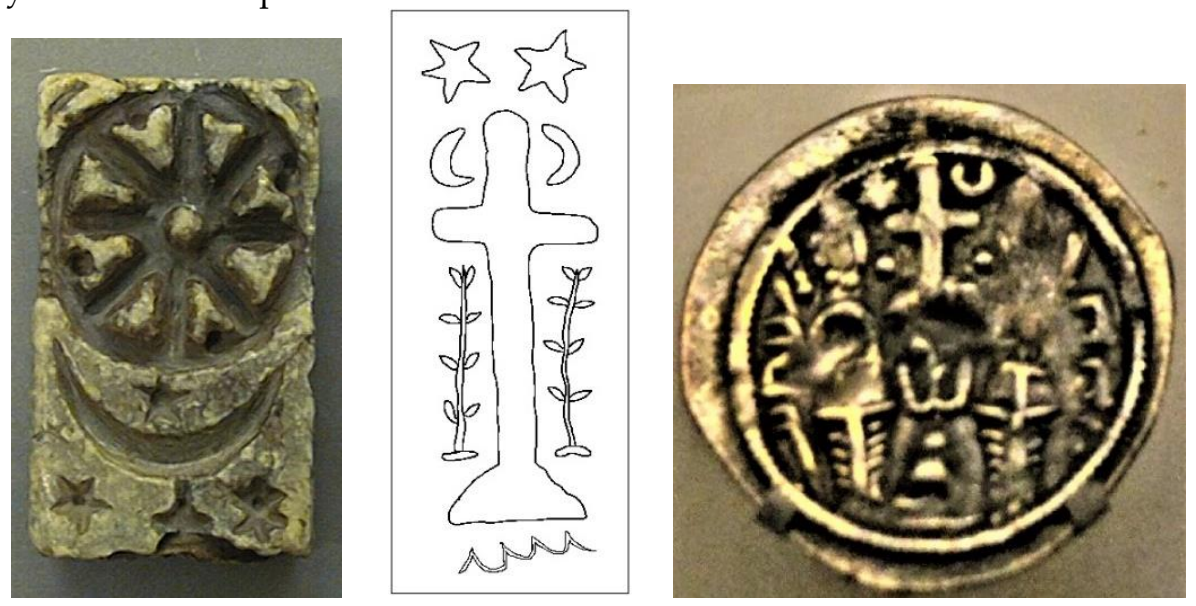

Photo 14. Crescent and sun disc, stamp, obverse (Photo: Courtesy of Benaki Museum)

Photo 15. Crescent and cross, stamp, side (Drawing: Nergis Ataç, 2018)

Photo 16. Crescent and cross, coin dated to the Sassanian period, (Tbilisi, Antique Archaeological Museum, 2018)

The tree of life and sun/star motifs might have played a role in the evolution of the leaved cross and crescent beneath the cross motifs. These symbols signify resurrection or God for some cultures but were used by the Turks and other cultures before and after they acquired meaning in Islam. ${ }^{34}$ How do the Turks relate to the leaved cross and the crescent beneath the cross? Some Turks were Pagans

\footnotetext{
33 The Byzantine Empire started in the tenth century to gradually re-conquer the Armenian and Georgian regions but ceased when the Turks invaded Anatolia.

${ }^{34}$ For the tree of life in the art of the Turks, see Bursalı, 2010, pp. 69-72.
} 
and some others were Orthodox or Nestorian Christians. Besides the tree of life, crescent and sun/star, Turks also were very familiar with the cross. But written sources barely mention some Turks' Christian faith. Additionally, the current archaeological data are insufficient to analyze Christianity among the Turks who migrated to Anatolia. Their number and density in specific regions are even harder to confirm.

On the other hand, coins with the illustration of Christ and the cross in the twelfth and thirteenth centuries prove that the H-J anonymous folles group was not a taboo to the Turks. Indeed, illustrations of the cross on Turkmen coins and the riders with the cross and star on Seljuq coins struck after agreements between the Seljuqs and Cilician Armenians prove the existence of coins decorated with depictions of mutual agreements between states (Photo 18). ${ }^{35}$
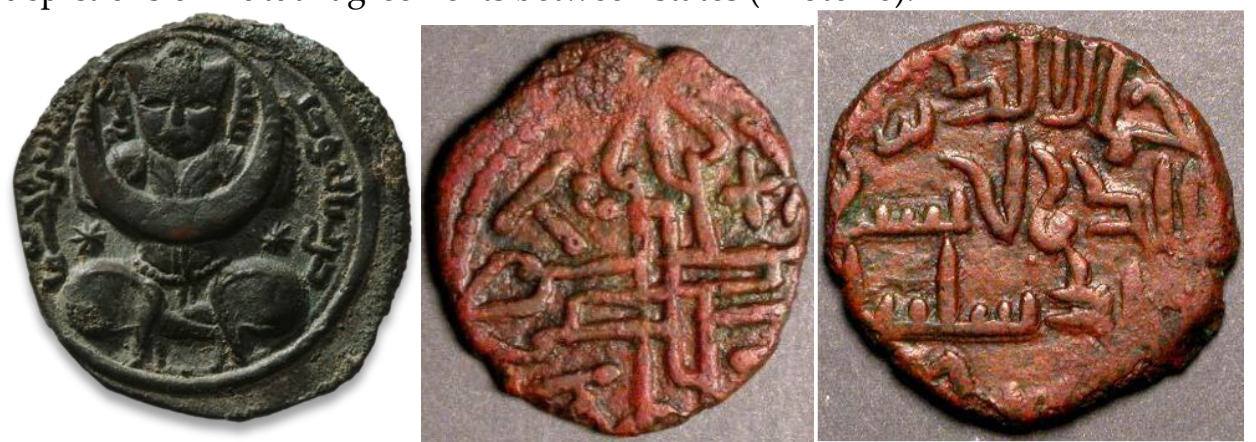

Photo 17. Zangid atabeg Izz al-Din Mas'ud I ibn Mawdud (1181-1193), copper dirham (1189), obverse

(https://mm.davidmus.dk/assets/348/coin_large/10-

8_C_557_o22_Photo_Pernille_Klemp.png)

Photo 18. Follis of Suleiman bin İshâk (1142-1177), cross and IC-XC-NI-KA,(Miynat, 2019, Şekil 6)2019, Şekil 6)

This leads again to the issue of the first coins used by the Seljuqs in their first years in Anatolia. The first certain coins struck by the Turks of Anatolia are dated to the first half of the twelfth century. ${ }^{36}$ It seems unlikely that Anatolia in the first half of the century lacked a coin mint, but from 1071 up to the second quarter of the twelfth century, the existence of a Turkic mint in Anatolia is unknown. There is another possibility: Coin mints in Melitene (Malatya), Sebasteia (Sivas), Amaseia (Amasya) and Iconion (Konya) were known to be active under the Turks in the twelfth and thirteenth centuries compel us to consider the possibility that some of

\footnotetext{
${ }^{35}$ For a specimen, see Parlar, 2001, No. 18.

36Sultan I. Rükne'd-Din Mesud's (1116/7-1156/7) coin is recorded as the first coin of the Rum Seljuqs (Parlar, 2001, p. 13).
} 
these mints may have been active in the eleventh century, as well. For example, the imitation of the Byzantine coin designs, rather than the Great Seljuqs or Abbasid ones, by the Turks of Anatolia give rise to the possibility of a continuity of provincial mint in the region. Thus, the Mardin and Diyarbakır hoards or the majority of the non-countermarked coins, compared with the countermarked anonymous folles found during excavations, supports the thesis of the widespread use of Byzantine folles-or copies of these folles- in regions ruled by the Turks. ${ }^{37}$ In this context, the relation of Byzantine emperors to the Seljuq emirs, the Christian inhabitants to the Seljuq rulers, must be explored. What mutual agreements for mining, minting and circulating coins might have existed between the Byzantine rulers, Seljuq rulers, and former Christian lords in the provinces to suit their various needs at that time? Siyavush (Chiauss), Malik Shah's appointee to meet emperor Alexius I, converted to Christianity in the empire and became the Duke of Achiate. ${ }^{38}$ Abu '1 Qasim was titled sebaste and carried a Roman scepter after the death of Suleiman Shah (Beihammer, 2017, p. 266). Çaka beg (Tzachas), honored as protonobilissime in the Byzantine court by Nicephoros III, was accepted as basileus in the Izmir region, when he took the opportunity to escape the capital isolated from Anatolia by the Turks (Anna Comnena, 2000, VII.VIII-IX, 129-132, IX.I, p. 152). While in the capital and court, he became well acquainted with Byzantine culture and state institutions. Additionally, agreements not only between courts but also between Christian people and Turks were arranged. When Philaretos left Antioch for a short period, he entrusted his duties to a Turk (Ismail). But, upon his return, he found the city delivered to Suleiman Shah by the Turk and his co-conspirator, Barsam, son of Philaretos, who was in prison (Altan, 2018, pp. 10-12). More important are the coins Suleiman Shah used while ruling Nicaea and Nicomedia. Suleiman Shah was officially recognized by Emperor Alexius I in 1081, ruled Antioch in 1085, and was called sultan in written sources. ${ }^{39}$ The lack of money minting during his and his sons' rule seems suspicious. Since Maliks were allowed to mint coins, and no strict central administration was imposed on Seljuq begs or the maliks of Anatolia, Suleiman Shah's coin dependence on Malik Shah, sultan of the Great Seljuqs, seems to be bare hypotheses. No coin is attributed to Suleiman

\footnotetext{
${ }^{37}$ For varieties, see Lowick, Bendall, \& Whitting, 1977. The majority of Group H-K folles in Mardin and Diyarbakır hoards compared with the West increase the possibility of a provincial mint.

${ }^{38}$ Alexius I gave many gifts to Siyavush (Chiauss). His mother was of Georgian origin and most likely Christian (Anna Comnena, 2000, VI.IX, p. 109).

${ }^{39}$ Although Byzantine authors portray him as sultan or amir with his own palace, Muslim authors state him as malik (subordinate of the sultan of the Great Seljuqs) (Anna Comnena, 2000., VI.X, p. 110; Mecit, 2014, pp. 26-27; Michael the Great, 1905, 3, pp. 175-176).
} 
Shah's rule and name. But he is recognized to have allowed local administrations to function under his name, while he exerted full control over security and military affairs. Local authorities or rebels are known to struck their own coins (e. g. Gabras, Toros, Philaretos, Mancaphas). The success or responsibilities of a local administration have yet to be disputed. Thus, the riches of Malatya brought an end to Gabriel $^{40}$.

\section{CONCLUSION}

Folles were struck not only in Constantinople, but also in other cosmopolitan centers such as Thessalonike, Trebizond, Antioch, and even in various small mint centers under the sovereignty of the Turks. In the second half of the eleventh century, Armenian-Georgian-Turk or Bulgarian-Slav-Petcheneg people lived together densely in Anatolia and the Macedonian regions. In their culture and religion, the tree of life, the cross, the crescent, and the sun/star symbols had significant importance. After losing power in the second half of the eleventh century, the Byzantine Empire survived several more centuries, due to its political success with these people and of course, contemporary world powers. The emperors, in order to eliminate or stop the independence of the people invading or conquering its lands, resorted to the ideology of political integration by making agreements with the new rulers of the lost territories and intended to assemble them under the cross and emperor. Although Attaleiates has not stated this exactly, the artistic development and influences in the region prove the thesis. Common symbols such as the living tree and crescent embraced all of these cultural and artistic influences, hence using them on coins could have been used to symbolize integration. On the other hand, the same political integration was also valid for the new rulers of Anatolia and the Balkans. The leaved crosses of the scepters of Maria Skleraina, Maria of Alania and Alexius I, revealing the change and development of the art of the capital and provinces, demonstrate that groups $\mathrm{H}, \mathrm{I}$ and J, M of the Byzantine anonymous folles are related but not limited to the capital.

\footnotetext{
${ }^{40}$ Gabriel was Philaretos's man. He previously governed Melitene under the rule of the Byzantine Empire, but when continuous incursions occurred from surrounding regions, he visited Malik Shah, and with his approval, he started to rule the city until 1101. The city was conquered by the Danishmendid in 1101. Gabriel was also appointed by Philaretos in the administration of Kharpet. The cities governed by him were rich in metal. In one of his seals, he is inscribed as kouropalatos and amir (Oikonomides, 1986, p. 103, No. 107).
} 


\section{REFERENCES}

Altan, E. (2018). Antakya Haçlı Prinkepsliği tarihi kuruluş devri (1098 - 1112). Ankara: Türk Tarih Kurumu Yay.

Anna Comnena (2000). Anna Comnena the Alexiad. (E. A. S. Dawes, Trans.). Ontario: Parentheses Publications Byzantine Series Cambridge.

Attaleiates, M. (2012). The history; Michael Attaleiates. (A. Kaldellis \& D. Krallis Trans.). Dumbarton Oaks Medieval Library. London: Harvard University Press.

Aytaç, İ. (2017). Harput iç kale kazılarında 2014-2015 sezonunda bulunan Bizans dönemi sikkeleri. Social Sciences, XII/(3), 140-153.

Aytaç, İ. (2018). Harput İç Kale kazılarında bulunan Artuklu dönemi sikkeleri. Fırat Üniversitesi Harput Araştırmaları Dergisi, V/(1), Elazı̆̆, 29-55. doi:10.12739/NWSA.2017.12.3.3C0162

Babayar, G. (2007). Köktürk Kağanlı̆̆ı sikkeleri kataloğu ; The catalogue of the coins of Turkic Qaghanate. Ankara: Türk İşbirliği Koordinasyan Ajansı Başkanlığı.

Beihammer, A. D. (2017). Byzantium and the emergence of Muslim-Turkish Anatolia, ca. 10401130. New York: Routledge.

Bellinger, A. R. (1928). The anonymous Byzantine bronze coinage. Numismatic Notes and Monographs, (35), 1-27.

Bendall, S. (1977). The mint of Trebizond under Alexius I and the Gabrades. The Numismatic Chronicle (1966) Seventh Series, XVII/(137), 126-136.

Brubaker, L. (2008). Vision and meaning in ninth-century Byzantium: image as exegesis in the homilies of Gregory of Nazianzus. (First published: 1999). Cambridge University Press, Cambridge.

Bryennios, N. (2008). Tarihin özü Niképhoros Bryennios. (Umar, B. Trans.), N. Başgelen (Ed.). İstanbul: Arkeoloji ve Sanat Yay.

Bursalı, M. (2010). Bir merkez sembolü olarak Bizans ve Selçuklu döneminde hayat ağacı motifi. In A. Ödekan, E. Akyürek \& N. Necipoğlu (Eds.), Onikinci ve onüçüncü yüzyıllarda Bizans dünyasında değişim, I. Uluslararası Sevgi Gönül Sempozyumu 25-28 Haziran 2007 Bildiriler (pp. 69-72). İstanbul: Vehbi Koç Vakfı.

Campagnolo-Pothitou, M. \& Cheynet, J.-C. (2016). Sceaux de la collection George Zacos au Musée d'Art et d'Histoire de Genève. Milan: Musée d'Art et d'Histoire de Genève.

Charanis, P. (1975). Cultural diversity and the breakdown of Byzantine power in Asia Minor. Dumbarton Oaks Papers, 29, 1-20. doi:10.2307/1291367

Cheynet, J.-C. (1996a). Pouvoir et contestation a Byzance (963-1210). (First Published: Sorbonne, 1990). Paris: Centre National de la recherche Scientifique et du Legs Malandrino.

Cheynet, J.-C. (1996b). Les Arméniens de l'empire en Orient de Constantin X à Alexis Comnène (1059-1081). In H. Ahrweiler \& N. Garsoian (Eds.), L'Armenie et Byzance: Histoire et culture (pp. 74-84). Paris: Publications de la Sorbonne.

Cheynet, J.-C. (2003). Official power and non-official power. In A. Cameron (Ed.), Fifty years of prosopography, the later Roman Empire, Byzantium and beyond (pp. 137-151). OxfordNew York: Oxford University Press. 
Cheynet, J.-C. (2006). The Duchy of Antioch during the second period of Byzantine rule. In

K. Ciggaar \& D. M. Metcalf (Eds.), East and West in the Medieval Eastern Mediterranean I: Antioch from the Byzantine reconquest until the end of the Crusader principality. Acta of the congress held at Hernen Castle in May 2003 (pp. 1-16). Leuven: Peeters.

Cheynet, J.-C. (2008). La société byzantine. L'apport des sceaux (Vols. 1-2). Paris: Association des amis du centre d'histoire et civilisation de Byzance.

Cheynet, J.-C., Gökyıldırım, T. \& Bulgurlu, V. (2012). Les scaux byzantins du Musée Archéologique d'Istanbul, E. G. Erdoğan (Ed.), İstanbul: İstanbul Araştırmaları Enstitüsü.

Croke, B. (2006). Justinian, Theodora, and the church of saints Sergius and Bacchus. Dumbarton Oaks Papers, 60, 25-63. Retrieved May 9, 2019, from http://www.jstor.org/stable/25046210

Demirel Gökalp, Z. (2009). Yalvaç Müzesi Bizans sikkeleri. Ankara: T. C. Kültür ve Turizm Bakanlığı, Kültür Varlıkları ve Müzeler Genel Müdürlüğü Yay.

Demirel Gökalp, Z. (2014). Malatya Arkeoloji Müzesi Bizans sikkeleri kataloğu. İstanbul: Arkeoloji ve Sanat Yay.

Diler, Ö. (2009). İslam darp yerleri/ Islamic mints (Vols. 1-3), E. N. Diler \& J. C. Hinrichs (Eds.). İstanbul: Garo Kü.

Evans, H. C. \& Wixom, W. D. (Eds.) (1997). The glory of Byzantium, art and culture of the Middle Byzantine era A.D. 843-1261. New York: The Metropolitan Museum of Art.

Garland, L. \& Rapp, Jr S. H. (2006). Mart'a-Maria 'of Alania', De Imperatoribus Romanis: An online encyclopedia of Roman rulers and their families, De Imperatoribus Romanis (DIR). Retrieved December 12, 2020, from http://www.roman-emperors.org/maryal.htm.

Garsoïan, N. G. (1998). The problem of Armenian integration into the Byzantine Empire. In H. Ahrweiler \& A. Laiou (Eds.), Studies on the international diaspora of the Byzantine Empire (pp. 53-124). Washington, DC: Dumbarton Oaks Trustees for Harvard University.

Georganteli, E. \& Cook, B. (2006). Encounters: travel and money in the Byzantine world. London: The Barber Institut of Fine Arts: D. Giles Ltd.

Grierson, P. (1993). Catalogue of the Byzantine coins in the Dumbarton Oaks collection and in the Whittemore collection (2nd ed.). [Vol. 2, (1st ed. 1968) 2nd ed. 1993], [Vol. 3, (1st ed. 1973), 2nd ed. 1993], A. R. Bellinger \& P. Grierson (Eds.). Washington D.C.: Dumbarton Oaks Research Library and Collection.

Hendy, M. F. (1999). Catalogue of the Byzantine coins in the Dumbarton Oaks Collection and in the Whittemore Collection, volume four Alexius I to Michael VIII 1081 to 1261. A. R. Bellinger \& P. Grierson (Eds.). Washington D.C.: Dumbarton Oaks Research Library and Collection.

Hewsen, R. H. (2001). Armenia: a historical atlas. Chicago: The University of Chicago Press.

Honigmann, E. (1970). Bizans devletinin doğu sinırı: Grekçe, arabca, süryanice ve ermenice kaynaklara göre 363'den 1071'e kadar (Iş1ltan, F. Trans.). İstanbul: İstanbul Üniversitesi Edebiyat Fakültesi Matbaası.

Jones, L. (2001-2002). The visual expression of Bagratuni rulership: ceremonial and portraiture. Revue des Études Arméniennes, 28, 341-398. doi: 10.2143/REA.28.0.505086 
Kalavrezou, I. (2011). Female popular beliefs and Maria of Alania. Journal of Turkish Studies, $36,85-101$.

Kılıç, S. (2016). Byzantine anonymous folles in the Bolu museum. Cedrus, 4, 315-339.

Lemerle, P. (1977). Cinq études sur le XIe siècle byzantine. Le Monde byzantin publié sous la direction de Paul Lemerle. Paris: Editions du Centre National de la Recherche Scientifique.

Lowick, N. M., Bendall, S. \& Whitting, P. D. (1977). The Mardin hoard, Islamic countermarks on Byzantine folles. Ringwood, Hampshire: A. H. Baldwin \& Sons Ltd.

Maguire, H. (1997). Images of the court. In H. C. Evans \& W. D. Wixom (Eds.), The glory of Byzantium, art and culture of the middle Byzantine era A.D. 843-1261 (pp. 183-192). New York: The Metropolitan Museum of Art.

Mecit, S. (2014). The Rum Seljuqs: evolution of a dynasty. London: Routledge.

Melikoff, I. (1960). La geste de Melik Dānişmend: étude critique du Dānişmendnāme (Vols. 1-2). (Melikoff, I. Ed. and trans.). Paris: Adrien Maisonneuve.

Metcalf, D. M. (1961). Provincial issues among the Byzantine bronze coinage of the eleventh century. Hamburger Beiträge zur Numismatik, 15, 25-32.

Metcalf, D. M. (1965). Coinage in the Balkans 820-1355. Thessaloniki: Institute for Balkan Studies.

Metcalf, D. M. (1970). Interpretation of the Byzantine 'Rex Regnantium' folles of class 'A' c. 970-1030. The Numismatic Chronicle (1966-), Seventh Series, 10, 199-219.

Metcalf, D. M. (2006). Six unresolved problems in the monetary history of Antioch, 929-1268. In K. Ciggaar and D. M. Metcalf (Eds.), East and West in the Medieval Eastern Mediterranean I: Antioch from the Byzantine reconquest until the end of the Crusader principality. Acta of the congress held at Hernen Castle in May 2003 (pp. 283-318). Leuven: Peeters.

Métivier, S. \& Prigent, V. (2010). La circulation monétaire dans la Cappadoce byzantine d'après les collections des musées de Kayseri et de Niğde. Travaux et Mémoires 16. 577-618. Hal id: halshs-00666332

Michael the Great (1905). Chronique de Michel le Syrien (Vol. 3). (J. -B. Chabot, Trans.). Paris: Ernest Leroux.

Morrisson, C. (2003). The emperor, the saint, and the city: coinage and money in Thessalonike from the thirteenth to the fifteenth century. Dumbarton Oaks Papers, 57, 173-203. doi:10.2307/1291880

Morrison, C. \& Schaaf, G.-D. (2015). Byzance et sa monnaie (IVe - XVe siècle). Précis de numismatique byzantine, suivi du catalogue de la collection Lampart à l'Université de Fribourg, 15. Paris: Réalités Byzantines.

Mousheghian, K., Mousheghian, A., Bresc, C., Depeyrot, G. \& Gurnet, F. (2000). History and coin finds in Armenia, coins from Ani, capital of Armenia (4th c. BC - 19th c. AD). Wetteren: Moneta.

Nesbitt, J., Oikonomides, N. \& McGeer, E. (1994-2005). Catalogue of Byzantine seals at Dumbarton Oaks and in the Fogg Museum of Art, Vols. 2-5 (J. Nesbitt and N. Oikonomides, Vol. 2, 1994; Vol. 3, 1996), (J. Nesbitt, E. McGeer, N. Oikonomides, Vol. 
4, 2001; Vol. 5, 2005), Washington, D.C.: Dumbarton Oaks Research Library and Collection.

Nesbitt, J., Wassiliou, A.-K. \& Seibt, W. (2009). Highlights from the Robert Hecht, Jr., collection of Byzantine seals, Thessaloniki: Aristotle University of Thessaloniki: Byzantine Research Center.

Oikonomides, N. (1986). A collection of dated Byzantine lead seals, Dumbarton Oaks: Research Library and Collection, Washington, D.C.

Papathanassiou, E. (2010-2015). The Armenian presence in and around the Rhodope Mountain in 11th C. Rethinking over some new archaeological finds. Peri Thrakis

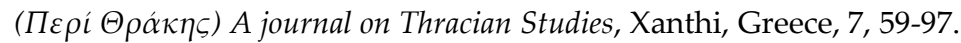

Parlar, G. (2001). Anadolu Selçuklu sikkelerinde yazı dışı figüratif öğeler. Ankara: Kültür Bakanlığı Yay.

Psellos, M. (1926). Michel Psellos chronographie ou histoire d'un siècle de Byzance (976-1077) (Vol. 1). E. Renauld (Ed. and trans.), Paris: Les Belles Lettres.

Rice, D. T. (1973). The leaved cross. Byzantine art and its influences (VII, pp. 72-81). London: Variorum.

Saminsky, A. (2006). Georgian and Greek illuminated manuscripts from Antioch. In K. Ciggaar \& D. M. Metcalf (Eds.), East and West in the Medieval Eastern Mediterranean I: Antioch from the Byzantine reconquest until the end of the Crusader Principality. Acta of the congress held at Hernen castle in May 2003 (pp. 17-78). Leuven: Peeters.

Saminsky, A. (2013). Assimilation and creation of Greek art in Antioch-on-the-Orontes in Syria during the second period of Byzantine domination (969-1084). In K. Ciggaar and V. V. Aalst (Eds.) East and West in the medieval eastern Mediterranean II Antioch from the Byzantine reconquest until the end of the Crusader Principality acta of the congress held at Hernen Castle (the Netherlands) in May 2006 (pp. 219-276). Leuven: Peeters.

Schlumberger, G. (1884). Sigillographie de l'empire byzantine. E. Leroux (Ed.). Paris: Librarie de la société de l'orient Latin.

Schulze, W. (2008). An anonymous copper coin re-attributed from Trebizond to Syria. The Numismatic Chronicle (1966-), 168, 321-330. Retrieved January 6, 2020, from http://www.jstor.org/stable/42678770

Schulze, W. \& Moesgard, J. C. (2005). A further hoard of tenth and eleventh century Byzantine folles with Arabic countermarks. The Numismatic Chronicle (1966-), 165, 339-347. Retrieved May 9, 2019, from http://www.jstor.org/stable/42667295

Seibt, W. (1976). Die Skleroi. Eine prosopographisch-sigillographische Studie. Wien: Verlag der Osterreichischen, Akademie der Wissenchaften.

Tekin, O. (2009). An Eleventh century hoard of Byzantine folles from the Marmaray - metro salvage excavation at Yenikap1 - İstanbul. Anatolia Antiqua, 17, 279-288. doi : https://doi.org/10.3406/anata.2009.1286

Tekin, O. (2014, Mart). Gre Amer höyüğü kazısından Armenia Kralı II. Artavazdes'in sikkesi. Toplumsal Tarih 243, 40-42.

Theophanes Continuatus (1838). Theophanes Continuatus Ioannes Camneiata, Symeon Magister, Georgius Monachus. I. Bekker (Ed.). Bonn: E. Weber. 
Thierry, N. (1971). B: The rock churches. L. Giovannini (Ed.), Arts of Cappadocia (pp. 129-171). Geneva: Nagel Publishing.

Thompson, M. (1954). Coins from the Roman through the Venetian period. The Athenian Agora, 2, iii-x+1-122. doi:10.2307/3601953

Tobias, N. (1969). Basil I (867-886), the founder of the Macedonian dynasty: a study of the political and military history of the Byzantine Empire in the ninth century. Unpublished $\mathrm{PhD}$ dissertation, New Jersey: New Brunswick, Rutgers University.

Ünal, C. (October 2010). A group anonymous folles from Kuva-yi Milliye Museum, Balıkesir/Turkey, Sanat Tarihi Dergisi, XIX/2, 85-108.

Ünal, C. (2012). Manisa Müzesi Bizans sikkeleri. Manisa: Celal Bayar Üniversitesi Yay.

Ünal, C. (2015). Bizans sikkelerinde kutsal kişi tasvirleri. Ankara: Türk Tarih Kurumu Yay.

Uykur, R. (Yaz-Summer 2017). Zengi atabeglerinin sikkelerinde antik Türk mitolojisinin izleri: Kağanlık simgesi olarak ay kültü (Mardin Müzesi örnekleri). Türk Dünyası Incelemeleri Dergisi/Journal of Turkish World Studies XVII/(1), 167-183.

Weitenberg, Jos J. S. (2006). The Armenian monasteries in the Black Mountain. K. Ciggaar \& D. M. Metcalf (Eds.), East and West in the Medieval Eastern Mediterranean I: Antioch From the Byzantine reconquest until the end of the Crusader Principality. Acta of the congress held at Hernen Castle in May 2003 (pp. 79-93). Leuven: Peeters. 
$60 \mid$ USAD Nergis ATAÇ 